\title{
Krónikus aortadissectio talaján kialakult thoracoabdominalis aneurysma endovascularis kezelése fenesztrált sztentgrafttal
}

\author{
Csobay-Novák Csaba dr. ${ }^{1,2}$. Entz László dr. ${ }^{3}$ \\ Banga Péter dr. ${ }^{2,3}$. Pólos Miklós dr. ${ }^{2,4}$ - Szabolcs Zoltán dr. ${ }^{2,4}$ \\ Csikós Gergely dr. ${ }^{2,5}$. Fontanini Daniele Mariastefano dr. ${ }^{1,2}$ \\ Vecsey-Nagy Milán dr. ${ }^{1}$. Szeberin Zoltán dr. ${ }^{2,3}$ \\ ${ }^{1}$ Semmelweis Egyetem, Általános Orvostudományi Kar, Városmajori Szív- és Érgyógyászati Klinika, \\ Intervenciós Radiológiai Tanszék, Budapest \\ ${ }^{2}$ Semmelweis Egyetem, Általános Orvostudományi Kar, Városmajori Szív- és Érgyógyászati Klinika, \\ Semmelweis Aortacentrum, Budapest \\ ${ }^{3}$ Semmelweis Egyetem, Általános Orvostudományi Kar, Városmajori Szív- és Érgyógyászati Klinika, \\ Érsebészeti és Endovaszkuláris Tanszék, Budapest \\ ${ }^{4}$ Semmelweis Egyetem, Városmajori Szív- és Érgyógyászati Klinika, Szívsebészeti Tanszék, Budapest \\ ${ }^{5}$ Semmelweis Egyetem, Általános Orvostudományi Kar, Aneszteziológiai és Intenzív Terápiás Klinika, Budapest
}

\begin{abstract}
Az aortadissectio krónikus stádiumában kialakuló thoracoabdominalis tágulatok megoldása multidiszciplináris megközelítést, nagy felkészültséget és fejlett technológiát igényel. A jellemzően többlépcsős mútétsorozat mortalitása és morbiditása az endovascularis technológia fejlődésével csökkent, de még mindig jelentős. A fenesztrált endovascularis aortamütét a thoracoabdominalis nyitott mütét alternatívája, mely kisebb mortalitással és morbiditással, rövidebb kórházi tartózkodással jár. Aortadissectio esetén történő alkalmazása az aorta lumenében lévő membrán miatt kihívást jelent. Esetbemutatásunkban egy 56 éves nőbeteget demonstrálunk, aki tíz évvel korábban A-típusú dissectio miatt aorta ascendens rekonstrukción esett át. A követés során csaknem a teljes aorta tágulata alakult ki, melynek megoldása három lépésben történt. Az első lépésben a disszekált aortaív nyitott mútétjét végeztük 'frozen elephant trunk' technikával, majd az aorta descendens tágulatának endovascularis kezelése történt sztentgraft-implantációval. A mútétsorozat záró lépése egy fenesztrált endovascularis aortaműtét volt, mely egyben ezen technikának az aortadissectio esetében történt első hazai alkalmazását jelenti.
\end{abstract}

Orv Hetil. 2021; 162(31): 1260-1264.

Kulcsszavak: aortadissectio, fenesztrált endovascularis aortamútét, thoracoabdominalis aneurysma

\section{Fenestrated endovascular repair of a thoracoabdominal aortic aneurysm in chronic dissection}

\footnotetext{
Thoracoabdominal aortic aneurysms developing in the chronic phase of an aortic dissection require multidisciplinary approach, experienced operators and advanced technology. The mortality and morbidity rate of these multistage operations were reduced with the latest technical achievements in endovascular repair, but they are still significant. Fenestrated endovascular aortic repair, an alternative of thoracoabdominal open repair, is associated with less mortality and morbidity, shorter hospital stay. Using fenestrated devices in aortic dissection is usually technically demanding due to the dissection membrane. We report the case of a 56-year-old woman, who underwent ascending aortic repair due to type A aortic dissection. During the follow-up, a large thoracoabdominal aneurysm developed involving also the arch. We performed a three-stage operation starting with the open repair of the aortic arch using a 'frozen elephant trunk' device followed by a thoracic endovascular aortic repair of the descending aorta. The final stage was a fenestrated endovascular aortic repair, which is the first use of this technique in aortic dissection in Hungary.
} 
Keywords: aortic dissection, fenestrated endovascular repair, thoracoabdominal aneurysm

Csobay-Novák Cs, Entz L, Banga P, Pólos M, Szabolcs Z, Csikós G, Fontanini DM, Vecsey-Nagy M, Szeberin Z. [Fenestrated endovascular repair of a thoracoabdominal aortic aneurysm in chronic dissection]. Orv Hetil. 2021; 162(31): 1260-1264.

(Beérkezett: 2021. január 5.; elfogadva: 2021. január 22.)

\section{Rövidítések}

3D = háromdimenziós; CT $=($ computed tomography) számí tógépes tomográfia; FEVAR $=($ fenestrated endovascular aortic repair) fenesztrált endovascularis aortamútét; USA = (United States of America) Amerikai Egyesült Államok

Fenesztrált sztentgraft első implantációjára (fenestrated endovascular aortic repair - FEVAR) 1996-ban került sor, széles körû elterjedése a 2000-es évekre esett [1]. Hazánkban a 2013-ban végzett első mútétet követően - az eszközök magas ára és a módszer egyelőre nem megoldott finanszírozása miatt - érdemi előrelépés néhány évig nem történt [2]. Ugyanakkor az utóbbi években egyre gyakrabban alkalmazzuk a FEVAR-t a degeneratív hátterü thoracoabdominalis aneurysmák kezelésében, mivel a hagyományos nyitott mútétnél lényegesen kisebb mortalitással és morbiditással, rövidebb kórházi tartózkodással jár [3-5]. Aortadissectióban történő alkalmazása azonban nagyobb kihívást jelent. Esetbemutatásunkkal egy aortadissectio talaján kialakult thoracoabdominalis tágulat többlépcsős mútéti rekonstrukcióját mutatjuk be, melynek záró mútéte egyben az aortadissectio miatt történt FEVAR első hazai alkalmazását is jelenti.

\section{Esetbemutatás}

Egy 56 éves, hypertoniás nőbeteg anamnézisében colon ascendens és transversum tumor miatt reszekció, majd varratelégtelenség miatt reoperációk szerepelnek. Az onkológiai követés során daganatmentesnek bizonyuló betegnél 2009-ben akut, Stanford A-típusú aortadissectio miatt más intézetben proximalis aortarekonstrukció történt poliészter graft interpozíciójával. A posztoperatív CT-angiográfiás felvételeken az aortaívtől a bal arteria (a.) iliaca communis bifurcatio szintjéig volt követhető a residualis dissectio, mely magában foglalta a supraaorticus ágak eredését, a teljes zsigeri szegmentumot és a bal a. iliaca communis bifurcatiót is. A truncus coeliacus, az a. mesenterica superior és a bal a. renalis a valódi lumenből, a jobb a. renalis az állumenből eredt. Mivel sem neurológiai tünetek, sem zsigeri ischaemia, sem alsó végtagi perfúziózavar nem jelentkezett, konzervatív terápia mellett döntött az őt kezelő szívsebész-munkacsoport. Az eset további kontrollját a kiterjedt aortabetegség miatt Klinikánk látta el. A dissectiót követően, kötőszöveti betegség gyanúja miatt indult genetikai vizsgálatok nem igazoltak örökletes kötőszöveti rendellenességet. Az évek során a disszekált aorta jelentősen tágult, 2019-ben mind a mellkasi, mind az infrarenalis szakaszon $6 \mathrm{~cm}$ feletti átmérőt ért el (1. ábra). Intézetünk multidiszciplináris aorta-munkacsoportjának döntése alapján mútétet javasoltunk. Az aortaív érintettsége miatt a thoracoabdominalis tágulat izolált megoldása nem volt lehetséges, ezért többlépcsős mútéti tervet állítottunk fel. Első lépésként az aortaív tágulatának sebészi rekonstrukciójára

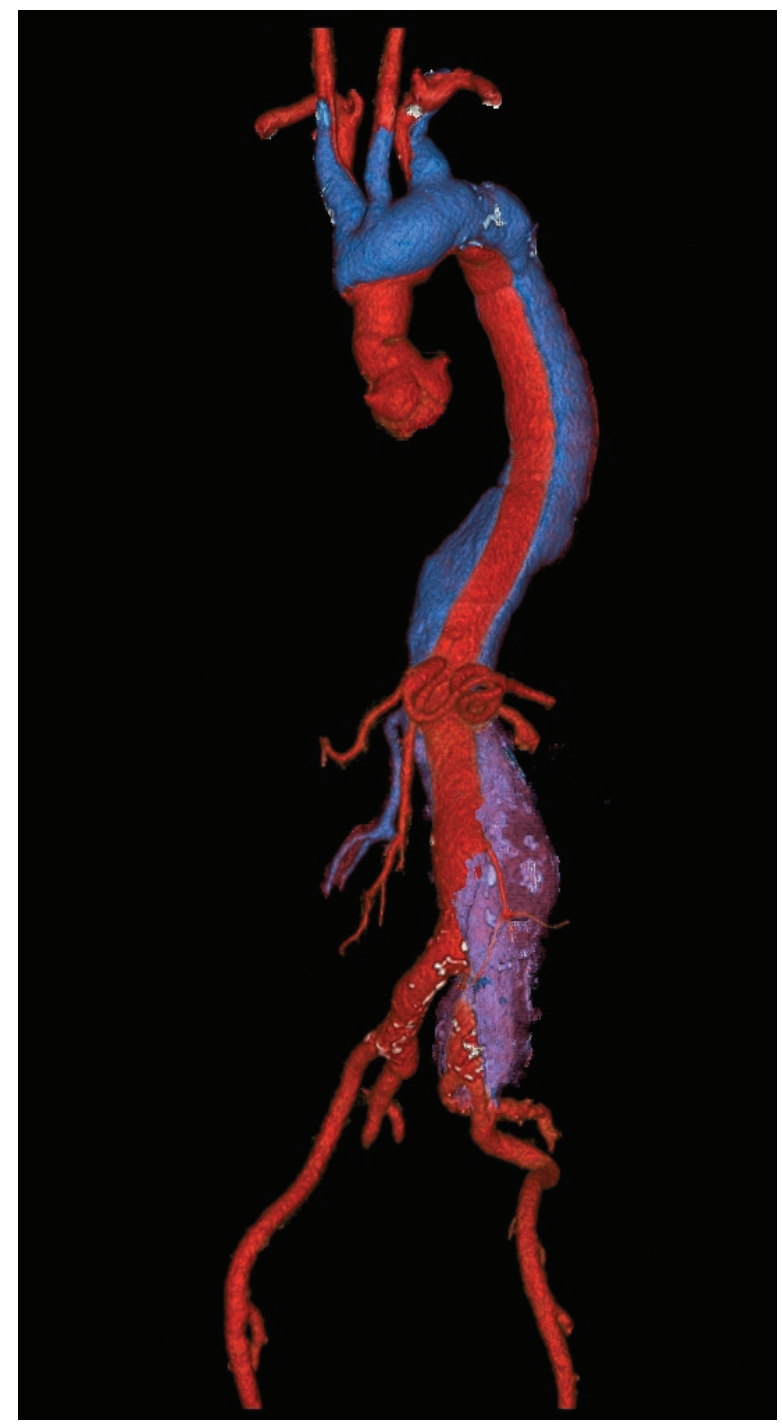

1. ábra Preopreatív CT-angiográfia 3D rekonstrukciója az aorta dissectiójával (piros: valódi lumen, kék: állumen)

3D = háromdimenziós; CT = számítógépes tomográfia 
volt szükség, ezt követte az aorta descendens, majd - végső lépésként - a visceralis szegmentum, az infrarenalis aorta és a bal a. iliaca communis residualis dissectiójának endovascularis kezelése.

A resternotomiával járó nyitott aortaív-rekonstrukció során ún. 'frozen elephant trunk' (merevített elefántormány ) mütétet végeztünk, $30 \mathrm{~mm}$ átmérőjű proximalis poliészter szegmenssel, valamint $32 \mathrm{~mm}$ átmérójü, 150 mm hosszúságú distalis sztentgraftszegmenssel rendelkező Vascutek Thoraflex Hybrid graft (Terumo Aortic, Vascutek Ltd., Inchinnan, Egyesült Királyság) implantációjával. A mütét során a supraaorticus értörzsek individuális reanastomosisát végeztük, aorta- és jobbpitvarkanülálás mellett. A 81 perces, mély hypothermiás keringésmegállással járó mütét során a motoridő 213 perc, a teljes mútéti idő 349 perc volt. Az eseménytelenül zajló mútétet követően fellépő légúti infekciók miatt elhúzódó gépi lélegeztetésre, tracheostomiára volt szükség. A beteget a 31. posztoperatív napon dekanüláltuk, és a 36. posztoperatív napon, javuló állapotban került sor rehabilitációs osztályra történő áthelyezésére.

Fél évvel később került sor az aorta descendens endovascularis kezelésére. Ennek során a jobb a. femoralis sebészi feltárásából egy $37 \mathrm{~mm}$ proximalis és $31 \mathrm{~mm}$ distalis átmérójú, 207 mm hosszúságú Medtronic Valiant Navion (Medtronic Inc., Minneapolis, MN, USA) sztentgraft implantációját végeztük, a korábban beültetett Thoraflex Hybrid grafttal történt széles átfedésben, a truncus coeliacus szájadékig. A graftnak az aorta valódi lumenében elfoglalt helyzetét a felvezetés közben transoesophagealis ultrahangvizsgálattal ellenőriztük. Erre a kis megterheléssel járó közbülső mütétre azért volt szükség, hogy a komprimált valódi lumen remodellációját elősegítsük, ezáltal a fenesztrált sztentgraft implantációját lehetővé tegyük, illetve csökkentsük a visceralis aortaszegmentum kezelése során fenyegető paraplegia kockázatát. Ez a mütét nem igényelt intenzív terápiás kezelést.

Ezt követően a visceralis szegmentum, az infrarenalis aorta és a bal a. iliaca communis bifurcatio endovascularis kezelése maradt hátra. A beavatkozást nehezítették: az aorta lumenének továbbra is komprimált volta; a valódi lumenból kiszakadt jobb veseartéria, melynek perfúzióját így csak az állumenen keresztülvezetett, ún. 'bridging' (áthidaló) sztenttel lehetett biztosítani; a bal a. iliaca communis teljes hosszának dissectiója. A paraplegia kockázatának csökkentése érdekében a thoracoabdominalis aortamútéteknél, így esetünkben is különösen fontos volt az a. iliaca interna védelme [6]. Mivel a bal iliacarendszeren a dissectio az externa eredésénél ért véget, az a. iliaca interna megtartása csak iliacabifurcatiós eszköz beültetésével volt lehetséges. Ezt azonban nehezítette, hogy a bal a. iliaca communis valódi lumene az ér proximalis szakaszán több centiméter hosszan elzáródott.

Több gyártóval, illetve külföldi centrummal történt konzultációt követően végül intézetünk multidiszciplináris aorta-munkacsoportja a visceralis aortaszegmen-

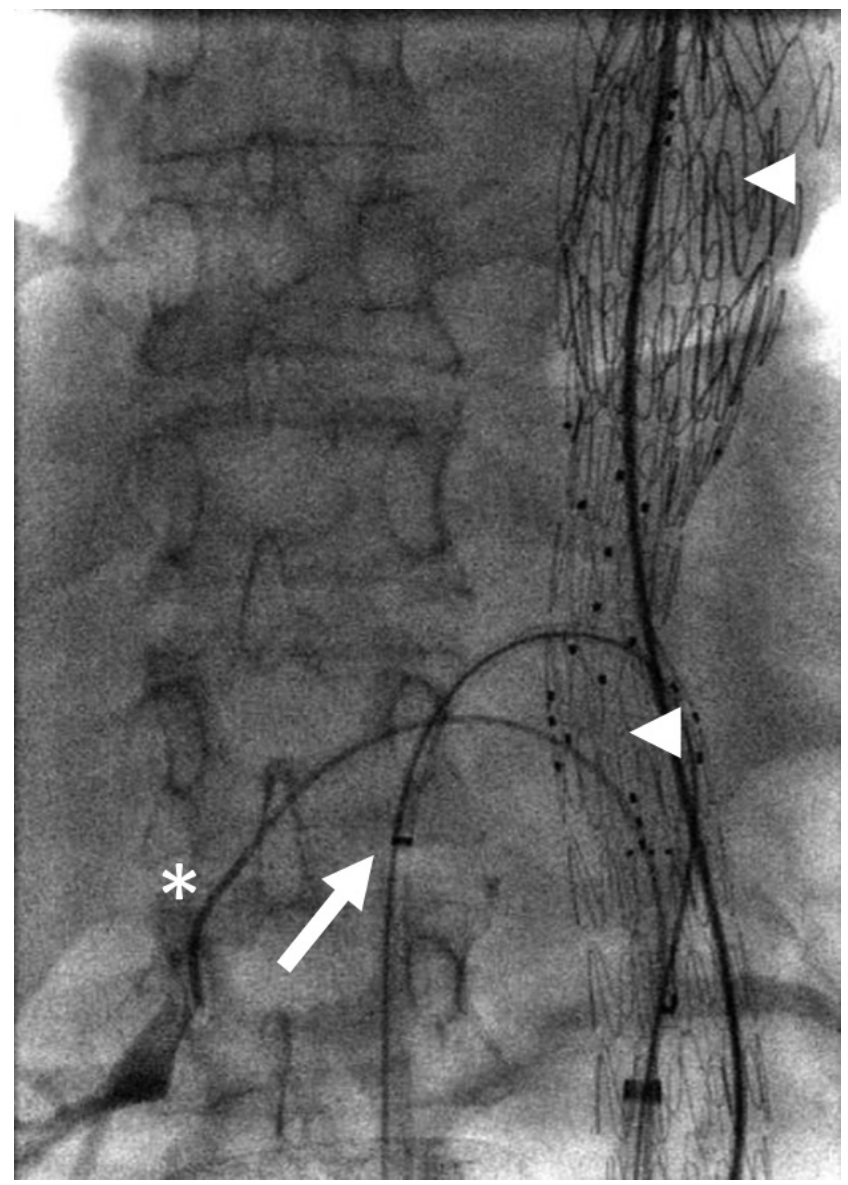

2. ábra

Intraoperatív fluoroszkópos felvétel a visceralis ágak kanüláció járól. Az aortában a fenesztrált főtest (nyílhegyek), az a. mesen terica superior vetületében 'sheath' (csillag), a jobb a. renalis vetületében diagnosztikus katéter (nyíl) látható

tum négyszeresen fenesztrált grafttal történő kezelése, a bal a. iliaca interna iliacabifurcatiós eszközzel történő megtartása mellett döntött, Cook Zenith (Cook Medical LLC, Bloomington, IN, USA) platformon, egyedileg gyártott graftokkal. A komponensek megtervezését és legyártását követően a mútétre a mellkasi sztentgraftimplantációt követő 5 . hónapban került sor. Kétoldali a. femoralis communis feltárást végeztünk. Jobb oldalról vezettük be a fenesztrált fótestet, melyet az oldalágakhoz illesztve részlegesen nyitottunk. Ezt követően bal oldalról rekanalizáltuk az a. iliaca communis elzáródott valódi lumenét, majd kanüláltuk a truncus coeliacus, az a. mesenterica superior és mindkét a. renalis lumenét (2. ábra). Az erekbe Flexor (Cook Medical LLC) 'sheath'-eken (hüvelyeken ) keresztül juttattuk be az áthidaló borított sztenteket (Bentley BeGraft Peripheral, Bentley InnoMed GmbH, Hechingen, Németország). Mind a négy ág kanülálását követően teljes átmérőre nyitottuk, majd elengedtük a fenesztrált főtestet, utána pozicionáltuk és nyitottuk az áthidaló borított sztenteket is. A borított sztentek proximalis végén Cook Advance 35 (Cook Medical LLC) 'semi-compliant' ballonnal végeztünk utótágítást („flaring”). 
A beavatkozást a bal iliacabifurcatiós fótest bevezetésével folytattuk. A graftot a bal a. iliaca communis rekanalizált valódi lumenében nyitottuk ki, majd a jobb femoralis felől átfordulva kanüláltuk a bal a. iliaca internát. 7 F átmérőjü Flexor 'sheath'-et juttattunk az érbe, majd pozicionáltuk az ide szánt, $10 \times 37$ mm-es Bentley BeGraft Peripheral eszközt, ügyelve az iliacabifurcatiós fótest és az internakomponens helyes pozíciójára, a két eszköz közötti optimális átfedésre. Ezután bevezettük a jobb femoralis felól az aortabifurcatiós fötestet, pozicionáltuk a fenesztrált komponenssel megfelelő átfedésben, majd kinyitottuk. Végül a bifurcatiós fótest és a bal iliacabifurcatiós graft közötti áthidaló elemet ültettük be. Az illesztéseken ballonos tágítást végeztünk 'compliant' ballonnal (Medtronic Reliant, Medtronic Inc.). A beavatkozás végén végzett angiográfián II. típusú 'endoleak' (áteresztés ) látszott, az elvégzett 'cone beam' (kúpsugaras) CT jó helyzetü, kellően expandált komponenseket mutatott. A kétoldali femoralis sebzá-

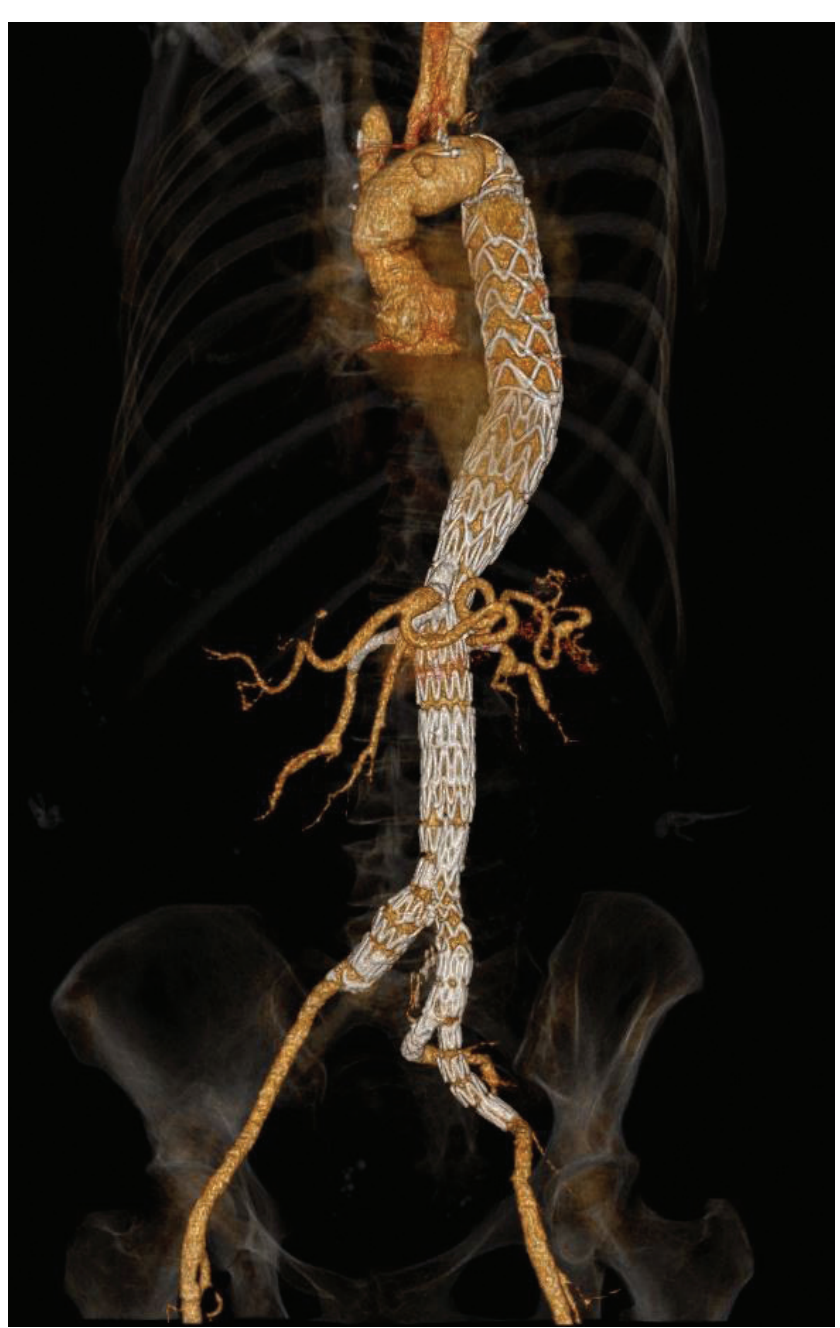

3. ábra

A beteg távozása előtt készített CT-angiográfia 3D rekonstrukciója

3D = háromdimenziós; CT = számítógépes tomográfia rást követő ébresztés után a beteg tünet- és panaszmentes volt. A 4. posztoperatív napon, az elbocsátás előtt végzett CT-angiográfián diszkrét telődés látszott az állumenben, lumbalis artériákkal, esetleg a jobb a. renalis graft illesztésével összefüggésben, mely miatt kontrollvizsgálatot tervezünk (3. ábra).

\section{Megbeszélés}

A FEVAR-mútétek során a krónikus dissectio talaján kialakult aortaaneurysmák kezelése lényegesen nagyobb kihívást jelent, mint a degeneratív aneurysmák ellátása. $\mathrm{Az}$ aorta lumenében lévő dissectiós membrán extrém mértékben megnehezíti a lumenben történő tájékozódást, pedig a graftok valódi lumenben történő elhelyezése alapvető fontosságú. Az oldalágak komplex eredési viszonyai is nehézséget jelentenek: ideális esetben a valódi lumenból erednek, néha azonban a szájadékukat érinti a dissectiós membrán, azon változó mértékú szúkületet okozva, mely kanülálási nehézséget jelent. Bizonyos esetekben a membrán teljesen kiszakad az ér szájadékából, ilyenkor fel kell keresnünk az intimamembránon lévő nyílást, majd az állumenen keresztüljutva kanülálnunk kell a célartériát. Esetünkben a jobb veseartéria kanülálását kellett ily módon elvégeznünk az intima körkörös kiszakadása miatt.

A thoracoabdominalis mútétek egyik legrettegettebb szövődménye a gerincvelő ischaemiás károsodása következtében kialakuló paraplegia. A súlyos komplikáció kockázata igazoltan csökkenthető a nagy aortamütétek több lépcsőben történő elvégzésével és bizonyos perioperatív manőverekkel, mint a cerebrospinalis folyadékdrenázs, az a. subclaviák és az a. iliaca internák megtartása, illetve a végtagok ischaemiás idejének csökkentése [7-9]. A fentiek miatt az aortaívtől az a. iliaca communis oszlásáig tartó műtétet három lépésben végeztük el, több hónapos szünetekkel: elsőként az aortaív nyitott mútéti ellátása történt 'frozen elephant trunk' eszközzel, majd az aorta descendens endovascularis mütéte, végül a visceralis szegmentum, az aorta és a bal a. iliaca communis bifurcatio endovascularis ellátása. A paraplegia rizikójának csökkentésére külön bifurcatiót terveztünk a bal a. iliaca communis oszlásába, megtartva a bal a. iliaca internát, bár az ezen a szakaszon elzáródott valódi lumen miatt ez csak ún. 'off-label' alkalmazással volt lehetséges. Ezen óvintézkedések mellett betegünknél a posztoperatív időszakban neurológiai tünetek nem jelentkeztek.

A szúk valódi lumenben számos eszközzel párhuzamosan történő manőverezés során lényegesen könnyíti a tájékozódást az ún. fúziós képalkotás. Ennek segítségével a beteg korábbi CT-angiográfiás vizsgálatából készített 3D modellt csontos tájékozódási pontok segítségével koregisztrálhatjuk, és a fluoroszkópia képére maszkként rávetíthetjük. Ennek használata igazoltan 
csökkenti a mútéti időt, a sugár- és kontrasztanyagdózist [10].

A beavatkozás végén a fix telepítésü angiográfiás berendezésen végzett 'cone beam' CT-vizsgálattal ellenőrizhetjük a beültetett komponensek optimális helyzetét, megfelelő expanzióját. Ennek használatával csökkenthetjük a reintervenciók számát [8].

A fent vázolt terápiás sorozat során külön feladatot jelentett a beteg együttmúködésének fenntartása. Ebben nagy segítséget jelentett az egyes mútétek időzítése és a szünetek időtartamának nem mindig rajtunk múló hoszsza. A köztes periódusok majdnem tünetmentes időszaka erősítette a beteget elhatározásában.

\section{Következtetés}

A krónikus dissectio talaján kialakult komplex aortaaneurysmák sikeres kezelése feltételezi a szívsebészeti, érsebészeti, intervenciós radiológiai, aneszteziológiai és képalkotói részvétellel történő multidiszciplináris megközelítést, valamint nagy felkészültséget és fejlett technikai hátteret igényel. Esetbemutatásunkban egy többlépcsős mütétsorozat sikerességéről számoltunk be, melynek záró mưtéte egyben az aortadissectióban történő FEVAR első hazai alkalmazását is jelenti.

Anyagi támogatás: A közlemény megírása és az ahhoz kapcsolódó kutatómunka anyagi támogatásban nem részesült.

Szerzői munkamegosztás: Cs.-N. Cs., B. P., Sza. Z., P. M., Cs. G., E. L., V.-N. M., F. D. M. és Sze. Z. a beteg kezelésében, a vizsgálat lefolytatásában, a kézirat megírásában és a beteg utánkövetésében tevékenykedett. B. P., Sza. Z., P. M., Cs. G., E. L. és Sze. Z. a cikk javításában és a végleges verzió kialakításában vett részt. A cikk végleges változatát valamennyi szerző elolvasta és elfogadta.

Érdekeltségek: A szerzőknek nincsenek érdekeltségeik.

\section{Irodalom}

[1] Park JH, Chung JW, Choo IW, et al. Fenestrated stent-grafts for preserving visceral arterial branches in the treatment of abdominal aortic aneurysms: preliminary experience. J Vasc Interv Radiol. 1996; 7: 819-823.

[2] Entz L, Nemes B, Szeberin Z, et al. Fenestrated stent-graft implantation in Hungary - Case report. [Fenesztrált stent-graft beültetés Magyarországon - Esetismertetés.] Magy Seb. 2015; 68: 88-93. [Hungarian]

[3] Verhoeven EL, Katsargyris A, Bekkema F, et al. Editor's Choice - Ten-year experience with endovascular repair of thoracoabdominal aortic aneurysms: results from 166 consecutive patients. Eur J Vasc Endovasc Surg. 2015; 49: 524-531.

[4] Oderich GS, Ribeiro M, Hofer J, et al. Prospective, nonrandomized study to evaluate endovascular repair of pararenal and thoracoabdominal aortic aneurysms using fenestrated-branched endografts based on supraceliac sealing zones. J Vasc Surg. 2017; 65: 1249-1259. el0.

[5] Coselli JS, LeMaire SA, Preventza O, et al. Outcomes of 3309 thoracoabdominal aortic aneurysm repairs. J Thorac Cardiovasc Surg. 2016; 151: 1323-1337.

[6] Wanhainen A, Verzini F, Van Herzeele I, et al. Editor's Choice - European Society for Vascular Surgery (ESVS) 2019 Clinical Practice Guidelines on the Management of Abdominal AortoIliac Artery Aneurysms. Eur J Vasc Endovasc Surg. 2019; 57: 8-93. [Erratum: Eur J Vasc Endovasc Surg. 2020; 59: 494.]

[7] Motta F, Crowner JR, Kalbaugh CA, et al. Outcomes and complications after fenestrated-branched endovascular aortic repair. J Vasc Surg. 2019; 70: 15-22.

[8] Spear R, Sobocinski J, Settembre N, et al. Early experience of endovascular repair of post-dissection aneurysms involving the thoraco-abdominal aorta and the arch. Eur J Vasc Endovasc Surg. 2016; 51: 488-497.

[9] Maurel B, Delclaux N, Sobocinski J, et al. The impact of early pelvic and lower limb reperfusion and attentive peri-operative management on the incidence of spinal cord ischemia during thoracoabdominal aortic aneurysm endovascular repair. Eur J Vasc Endovasc Surg. 2015; 49: 248-254.

[10] Doelare SA, Smorenburg SP, van Schaik TG, et al. Image fusion during standard and complex endovascular aortic repair, to fuse or not to fuse? A meta-analysis and additional data from a singlecenter retrospective cohort. J Endovasc Ther. 2021; 28: 78-92.

(Csobay-Novák Csaba dr., Budapest, Határőr út 18., 1122 e-mail: csobay.csaba@med.semmelweis-univ.hu)

A cikk a Creative Commons Attribution 4.0 International License (https://creativecommons.org/licenses/by/4.0/) feltételei szerint publikált Open Access közlemény, melynek szellemében a cikk bármilyen médiumban szabadon felhasználható, megosztható és újraközölhető, feltéve, hogy az eredeti szerző és a közlés helye, illetve a CC License linkje és az esetlegesen végrehajtott módosítások feltüntetésre kerülnek. (SID_1) 